\title{
Optimization of culture media to produce Bacillus subtilis strain QST 713 in a handcrafted bioreactor
}

\author{
Valera- Montero, L.L. ${ }^{1}$; González-Delgadillo, L. ${ }^{1}$; Amador-Rodríguez, K. A. ${ }^{1}$; \\ Perales-Segovia, C. ${ }^{1}$; Flores-Benítez, Silvia ${ }^{1 *}$ \\ 1 Tecnológico Nacional de México/Instituto Tecnológico El Llano Aguascalientes. Km 18, Carretera \\ Aguascalientes-San Luis Potosí, El Llano, Aguascalientes, CP 20330. Aguascalientes, México. \\ * Correspondence: silvia.fb@llano.tecnm.mx
}

\begin{abstract}
Objective. To optimize a nutrient medium based on fertilizers for the cultivation of Bacillus subtilis in an Airlift-type handcrafted bioreactor.

Design/Methodology/Approach. Twenty-seven nutrient media, fixed by combining five factors with three levels, including sucrose, ammonium sulfate, triple superphosphate, UltraK ${ }^{\circledR}$ formula, and B. subtilis inoculum (Serenade ${ }^{\circledR}$ Max) were tested in a 50L handcrafted by the authors. The variables monitored in the media were absorbance, dissolved oxygen, $\mathrm{pH}$, and temperature. The first was the one that was considered for optimization as it is the indirect indicator of bacterial growth. On the statistical analysis, the option "Larger is better" was chosen for Signal/Noise for the ANOVA of the main effects according to the Taguchi method.

Results. The highest level of sucrose, together with the lowest level of triple superphosphate were determinants for maximum growth of Bacillus in the time studied. On the other hand, the components such as ammonium sulfate, UltraK ${ }^{\circledR}$ formula, or the amount of inoculum were not significant, which means that they can be added from the mid to low levels.

Study limitations/Implications. This new information can be scaled to bioreactors of $2500 \mathrm{~L}$ for B. subtilis that we have previously developed.

Finding/Conclusions. Maximum bacterial growth depends on a good supply of sucrose, limiting triple superphosphate. Additionally, it is prudent to decrease additions of ammonium sulfate because it reduces dissolved oxygen in the nutrient medium.
\end{abstract}

Keywords: nutrient broth, optimization, airlift bioreactor, Bacillus subtilis.

Gitation: Valera-Montero, L.L., González-Delgadillo, L., AmadorRodríguez, K. A., Perales-Segovia, C., \& Flores-Benítez, S. (2021).

Optimization of culture media to produce Bacillus subtilis strain QST 713 in a handcrafted bioreactor Agro Productividad. https://doi. org/10.32854/agrop.vl4i9.2123

Editor in Chief: Dr. Jorge Cadena Iñiguez

Received: April 23, 2021. Accepted: August 11, 2021.

Published on-line: October 12, 2021

This work is licensed under a Creative Commons Attribution-NonCommercial 4.0 International license.

\section{INTRODUCTION}

Bioreactors

used

for

experimentation tend to be expensive equipment, even those with a capacity of 10 or fewer liters since their cost usually exceeds $€ 20,000$; and the possibility of its acquisition is usually remote for laboratories in general, for which researchers implement their designs, but they are usually handcrafted and low-capacity models (Lamping, 2004; SerratDíaz \& Méndez-Hernández, 2015).

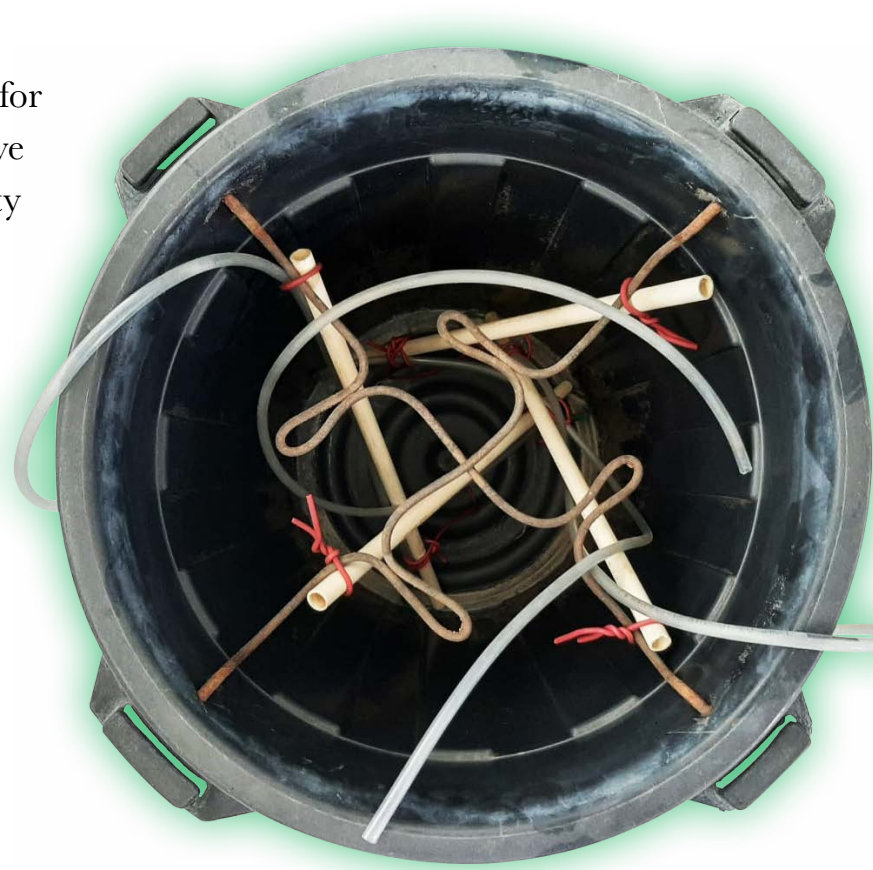


There are examples of the performance of small factory-built bioreactors, with tests using E. coli and media prepared from basic reagents that are not economical for application outside of medicine (Schirmer et al., 2019). Others, who are the vast majority, prefer simplicity when using bioreactors that work by shaking, with even smaller culture volumes (Carvalho et al., 2010). In these cases, researchers carry out $90 \%$ of the culture experiments in these bioreactors and less than $2 \%$ of the publications mention the engineering aspects of the equipment, with some exceptions (Bourne et al., 1992; Büchs, 2001).

However, massive, or commercial production of beneficial microorganisms for agriculture from the practical point of view occurs in fermenters or bioreactors, and to achieve this, it is necessary to previously make a good choice of the microorganism, its culture medium or its optimization and a good start-up of the fermentation process (Seletzky et al., 2007). And if the production, of beneficial microorganisms, is approached from the economic point of view, then its application to crops becomes exclusive to a small sector of farmers who have enough money to do it. These high prices for both the reactor, its operation, and its culture media, have led some to consider the need to lower costs based on the concept "Do it yourself". Under this condition, control focuses on simple monitoring of optical density, fluorescence, $\mathrm{pH}$, and dissolved oxygen; all of this at affordable prices. These alternatives have a high degree of flexibility for different applications and requirements in the design and construction of simple bioreactors (Pilizota \& Yang, 2018; Theodore et al., 2019). At the same time, this type of reactor can also enhance what has been called "synthetic biology", as it includes genetically modified microorganisms that can be used in the development of new products, with a regulated expression of metabolic routes or with the introduction of new routes, becoming in factories of biological products (Pleiss, 2006; Scognamiglio et al., 2015). Then, the task of bioengineers is to grow microorganisms of interest, at higher speeds than those that occur in nature in containers that contain the nutrients and the optimal aeration and temperature conditions (Galindo et al., 2007).

Therefore, the objective of this work was to optimize a nutrient medium based on fertilizers for the cultivation of Bacillus subtilis in an Airlift-type bioreactor. This handcrafted Airlift-type bioreactor is of our own design with a volume of 50 liters of capacity, in which performance tests were carried out with different media considering the basic variables previously mentioned. Although there are typical batch Airlift bioreactors (Katoh \& Yoshida, 2009) described as internal lift (IL) and external lift (EL) of turbulent motion, it is important to note that the bioreactor presented in this work is a variant of the first case and that promotes excellent aeration and movement of the culture medium.

\section{MATERIALS Y METHODS}

Our group has experience in the construction of a fully operating 2500-liter Airlifttype bioreactor to produce Bacillus subtilis for direct application in the irrigation of chili pepper cv. 'Sequoia' for the control of Phytophthora capsici in an agricultural company in the municipality of Pabellón de Arteaga, Aguascalientes (Paulino-Martínez, 2017). In this study, the goal was to optimize the materials used for the preparation of the culture medium in a small-scale artisanal bioreactor. 


\section{Bioreactor characteristics}

The present study was intended to optimize the use of material inputs to reduce broth costs; and to carry out experiments, a 50-liter reactor was used under laboratory conditions. This was devised in a 60-liter container with metal supports to fix four PVC pipes of $1 / 2$ " diameter by $50 \mathrm{~cm}$ long submerged and in an inclined position. The pipes were fed separately in the lower part using fish tank tubing so that each of the four pipes would bubble freely. This feeding was carried out using two double-outlet air pumps for fish tanks (Elite $799^{\circledR}$, Hagen HA799).

\section{Raw materials for the nutritive broth}

To make the estimates of the basic nutrient requirements, several studies were consulted that report the maximum biomass and the dry matter obtained in bioreactors, as well as the elemental composition of the bacteria (Matar et al., 2009; Bratbak, \& Dundas, 1984; Glazyrina et al., 2010; Novoselov et al., 2013). In addition, the appropriate materials for the preparation of the broth were reviewed (Hernández-Bustos, 2003). Based on the above, it was determined to use commercial sucrose, ammonium sulfate, triple superphosphate powder (ground), and UltraK ${ }^{\circledR}$. All of these, except for sucrose, are fertilizers or agrochemicals that are easily available and cheaper than laboratory reagents. These materials proved to be suitable for the rapid growth of B. subtilis.

\section{Bacterial strain}

Previously, in the use of our artisanal Airlift reactors in the field (Paulino-Martínez, 2017), Bacillus subtilis strain QST 713 (Serenade ${ }^{\circledR}$ Max, Bayer; AgraQuest, 2001) was used since according to farmers it provides adequate protection against $P$. capsici. For this reason, this strain was kept being part of this study to optimize the factors of its production.

\section{Data recorded}

Variables measured were turbidity (Absorbance at $\lambda=600 \mathrm{~nm}$ ) using a visible light spectrophotometer (Spectronic ${ }^{\circledR}$ 20D, Milton Roy Co.), dissolved oxygen using a sensor (LAQUA act, DO120, Horiba), pH (pH meter WT-40, AMPROBE) and temperature using a glass thermometer. Each variable was measured every hour during $12 \mathrm{~h}$ for the 27 runs.

\section{Treatment design}

The treatment design was done under the Taguchi method with five factors and three levels per factor. Table 1 shows the factors and levels, defined in grams/50 L. The data analyzed were those of the last measurement.

The resulting data were subjected to the analysis of variance of means and signal-tonoise using Minitab ${ }^{\circledR}$ software (version 16) to determine the importance or contribution of the studied factors in the measured variables. The analysis was performed with the Signal/Noise option "Larger is better" $(S / N)_{L}=-10 * \log _{10}\left\{\sum\left(1 / y^{2}\right) * 1 / n\right\}$ (Cruz-Trejos 
Table 1. Levels for raw materials used for the preparation of the nutritive broth of the $50 \mathrm{~L}$ bioreactor.

\begin{tabular}{l|c|c|c}
\multicolumn{1}{c|}{ Material (Factor) } & Low $(\mathbf{g})$ & Medium $(\mathbf{g})$ & High $(\mathbf{g})$ \\
\hline Sucrose (commercial type) & 154.5 & 463.5 & 772.5 \\
\hline Ammonium Sulfate & 60.5 & 181.5 & 302.5 \\
\hline Triple Superphosphate & 6.3 & 18.9 & 31.5 \\
\hline Ultra K ${ }^{\circledR}$ & 1.05 & 3.15 & 5.25 \\
\hline Inoculum (Serenade ${ }^{\circledR}$ Max $)$ & 1.1 & 3.3 & 5.5 \\
\hline
\end{tabular}

et al., 2012). The 27 combinations or runs generated by Minitab $16^{\circledR}$ according to the Taguchi design in $\mathrm{g} / 50 \mathrm{~L}$ appear in Table 2.

Table 2. Runs or combinations of the nutrient broth for the bioreactor $(\mathrm{g} / 50 \mathrm{~L})$.

\begin{tabular}{|c|c|c|c|c|c|}
\hline Run & Sucrose $(g)$ & $\begin{array}{l}\text { Ammonium } \\
\text { sulfate }(g)\end{array}$ & $\begin{array}{c}\text { Triple } \\
\text { Superphosphate }(\mathrm{g})\end{array}$ & Ultra $K^{\circledR}(\mathbf{g})$ & Serenade $^{\circledR}(\mathrm{g})$ \\
\hline $\mathrm{L}_{1}$ & 154.5 & 60.5 & 6.3 & 1.05 & 1.1 \\
\hline $\mathrm{L}_{2}$ & 154.5 & 60.5 & 6.3 & 1.05 & 3.3 \\
\hline $\mathrm{L}_{3}$ & 154.5 & 60.5 & 6.3 & 1.05 & 5.5 \\
\hline $\mathrm{L}_{4}$ & 154.5 & 181.5 & 18.9 & 3.315 & 1.1 \\
\hline $\mathrm{L}_{5}$ & 154.5 & 181.5 & 18.9 & 3.315 & 3.3 \\
\hline $\mathrm{L}_{6}$ & 154.5 & 181.5 & 18.9 & 3.315 & 5.5 \\
\hline $\mathrm{L}_{7}$ & 154.5 & 302.5 & 31.5 & 5.25 & 1.1 \\
\hline $\mathrm{L}_{8}$ & 154.5 & 302.5 & 31.5 & 5.25 & 3.3 \\
\hline $\mathrm{L}_{9}$ & 154.5 & 302.5 & 31.5 & 5.25 & 5.5 \\
\hline $\mathrm{L}_{10}$ & 463.5 & 60.5 & 18.9 & 5.25 & 1.1 \\
\hline $\mathrm{L}_{11}$ & 463.5 & 60.5 & 18.9 & 5.25 & 3.3 \\
\hline $\mathrm{L}_{12}$ & 463.5 & 60.5 & 18.9 & 5.25 & 5.5 \\
\hline $\mathrm{L}_{13}$ & 463.5 & 181.5 & 31.5 & 1.05 & 1.1 \\
\hline $\mathrm{L}_{14}$ & 463.5 & 181.5 & 31.5 & 1.05 & 3.3 \\
\hline $\mathrm{L}_{15}$ & 463.5 & 181.5 & 31.5 & 1.05 & 5.5 \\
\hline $\mathrm{L}_{16}$ & 463.5 & 302.5 & 6.3 & 3.315 & 1.1 \\
\hline $\mathrm{L}_{17}$ & 463.5 & 302.5 & 6.3 & 3.315 & 3.3 \\
\hline $\mathrm{L}_{18}$ & 463.5 & 302.5 & 6.3 & 3.315 & 5.5 \\
\hline $\mathrm{L}_{19}$ & 772.5 & 60.5 & 31.5 & 3.315 & 1.1 \\
\hline $\mathrm{L}_{20}$ & 772.5 & 60.5 & 31.5 & 3.315 & 3.3 \\
\hline $\mathrm{L}_{21}$ & 772.5 & 60.5 & 31.5 & 3.315 & 5.5 \\
\hline $\mathrm{L}_{22}$ & 772.5 & 181.5 & 6.3 & 5.25 & 1.1 \\
\hline $\mathrm{L}_{23}$ & 772.5 & 181.5 & 6.3 & 5.25 & 3.3 \\
\hline $\mathrm{L}_{24}$ & 772.5 & 181.5 & 6.3 & 5.25 & 5.5 \\
\hline $\mathrm{L}_{25}$ & 772.5 & 302.5 & 18.9 & 1.05 & 1.1 \\
\hline $\mathrm{L}_{26}$ & 772.5 & 302.5 & 18.9 & 1.05 & 3.3 \\
\hline $\mathrm{L}_{27}$ & 772.5 & 302.5 & 18.9 & 1.05 & 5.5 \\
\hline
\end{tabular}




\section{RESULTS AND DISGUSSION}

The bioreactor worked perfectly for the $27,12 \mathrm{~h}$ runs causing the culture medium to move in a spiral-upward way, creating a clockwise movement bubbling through the pipes. In none of the cases was the accumulation of sediment or precipitate observed inside the bioreactor (Figure 1).

\section{Turbidity}

All the media studied were translucent at the time of preparation and subsequently, their maximum turbidity increased at the end of $12 \mathrm{~h}$ in which each of the broth was being monitored (Figure 2). This means that there was sustained bacterial growth in all cases, but not in all cases the same growth was obtained. The treatments that obtained the highest turbidity at the end of $12 \mathrm{~h}$ were: $\mathrm{L}_{22}, \mathrm{~L}_{26}, \mathrm{~L}_{23}$, and $\mathrm{L}_{24}$ (Table 2, Figure 2). In a subsequent analysis of the turbidity, taking into account the last measurement, significance was found $p=0.001$ for the commercial sugar factor (sucrose) and $p=0.054$ for the triple

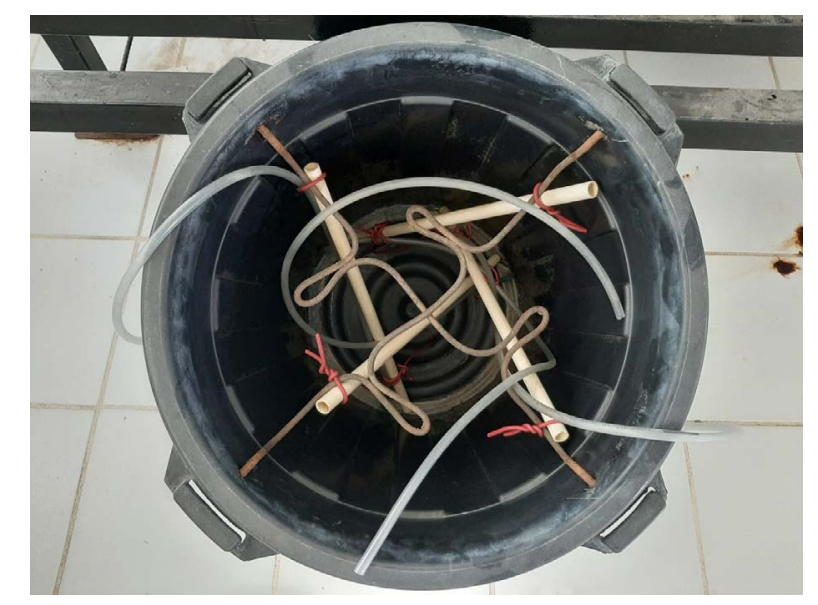

Figure 1. Arrangement of the artisanal Airlift bioreactor.

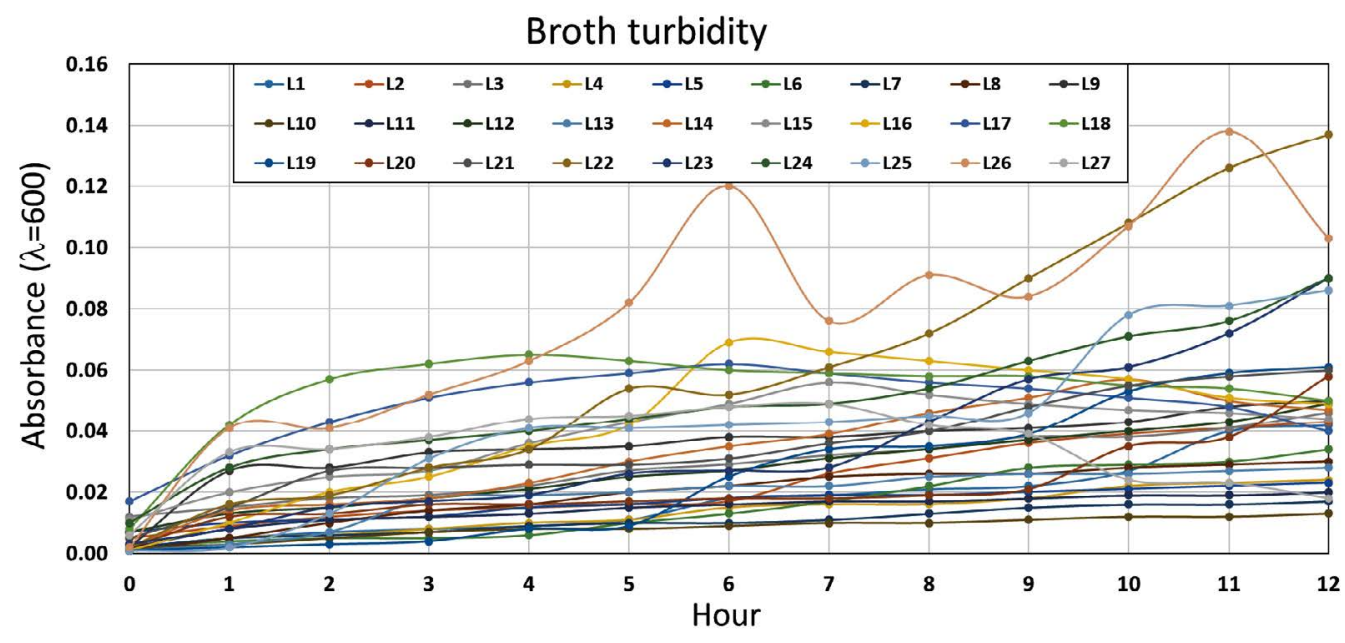

Figure 2. Evolution of the turbidity of the 27 media in $12 \mathrm{~h}$ of culture. 
superphosphate factor (Figure 3). The rest of the factors seemed not to have significance. Taking the matching levels of these treatments, all have the maximum amount of sucrose, and triple superphosphate mainly at the lowest or medium values. The addition of UltraK ${ }^{\circledR}$ or the dosage did not result in notable differences.

Checking the graphs of the main effects of each of the factors and taking into account the analysis of variance of the turbidity means, it was observed that the maximum value was achieved when the sugar level was the highest $(772.5 \mathrm{~g} / 50 \mathrm{~L})$. On the other hand, triple superphosphate had a negative influence at medium and high levels, since the highest bacterial growth was observed when $6.3 \mathrm{~g} / 50 \mathrm{~L}$ were added (Figure 4).

For non-significant main effects (Figure 3), the lowest or medium levels can be taken without influencing the results. In this case, the criterion for selecting the best level turns out to be economic, that is, it is better to take lower levels for ammonium sulfate, UltraK ${ }^{\circledR}$, and the inoculum dose without diminishing bacterial growth.

\begin{tabular}{lrcrrrc}
\multicolumn{7}{c}{ ANOVA FOR TURBIDITY } \\
SOURCE & GL & SS & Adj. SS & Adj. MS & \multicolumn{1}{c}{ F } & P \\
\hline Sucrose (g) & 2 & 0.010665 & 0.010665 & 0.005333 & 11.95 & 0.001 \\
Ammonium sulfate (g) & 2 & 0.000878 & 0.000878 & 0.000439 & 0.98 & 0.396 \\
Triple superphosphate (g) & 2 & 0.003133 & 0.003133 & 0.001566 & 3.51 & 0.054 \\
Ultra K (g) & 2 & 0.000529 & 0.000529 & 0.000265 & 0.59 & 0.564 \\
Inoculum (g) & 2 & 0.000016 & 0.000016 & 0.000008 & 0.02 & 0.982 \\
Error & 16 & 0.007141 & 0.007141 & 0.000446 & & \\
Total & 26 & 0.022362 & & & &
\end{tabular}

Figure 3. Analysis of variance of means of the absorbance variable $(\lambda=600 \mathrm{~nm})$.

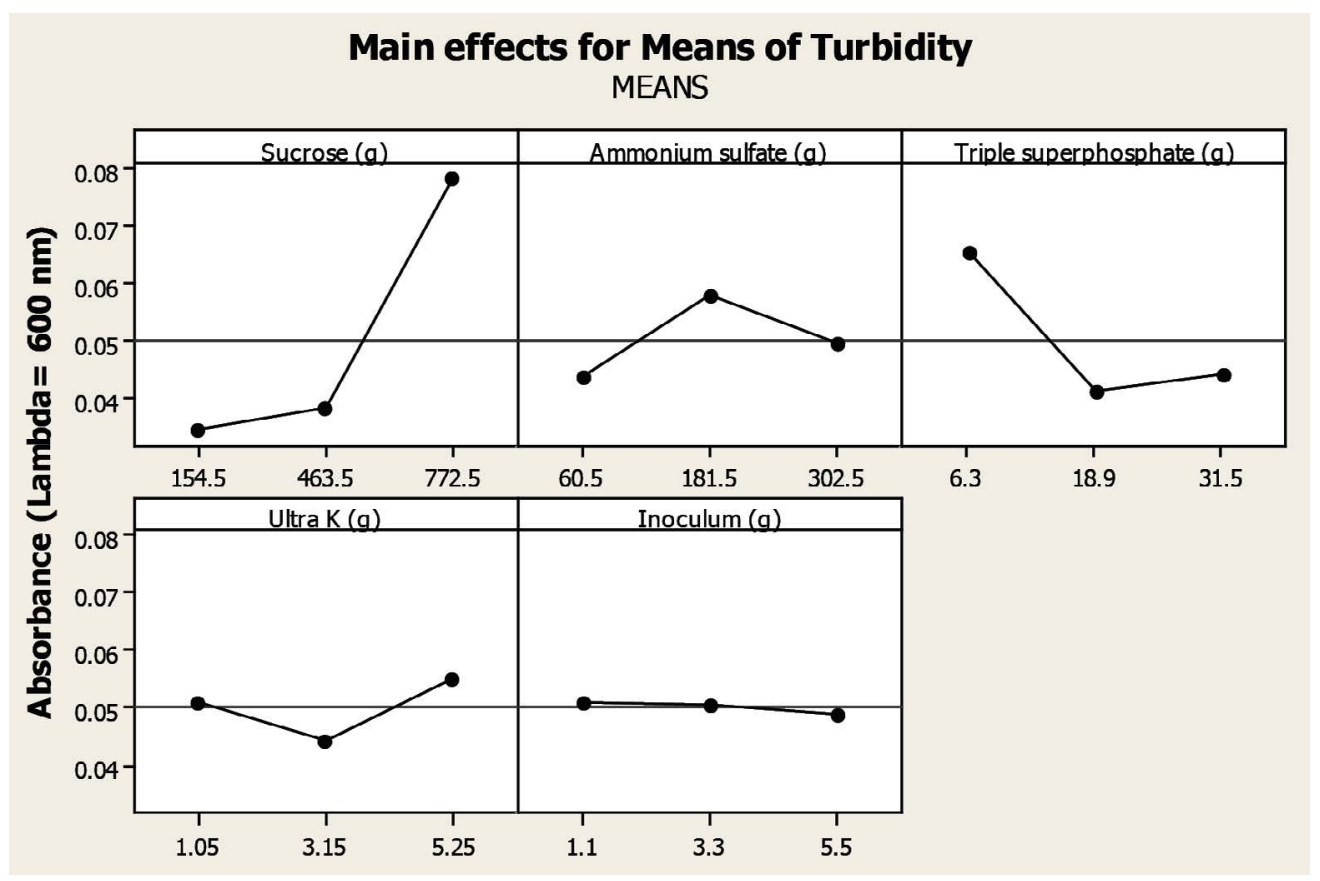

Figure 4. Graphical analysis of the turbidity means (absorbance $\lambda=600 \mathrm{~nm}$ ) from nine replications. 
Confirmation of the above results is also observed in the analysis of variance of the relationships $(S / N)_{L}$, as mentioned by Cruz-Trejos et al.(2012). Again, the significant factors were only for sugar (sucrose) $p=0.006$ and triple superphosphate $p=0.047$; meanwhile, the rest of the factors were not significant (Figure 5). Coincidentally with the previous graph of the main effects of the means, in the analysis for the $\mathrm{S} / \mathrm{N}$ values, the highest level of sucrose induced the highest turbidity, and the lowest level of triple superphosphate was the one that allowed growth bacterial and, therefore, the highest turbidity. In the rest of the factors, there are no major changes in the main effects.

By selecting the media that showed the highest turbidity $12 \mathrm{~h}$ after starting the culture, it was found that they contained the highest level of sucrose and most contained the lowest level of triple calcium superphosphate, matching with the graphic analysis of the main effects both for means and for Signal/Noise (Table 3).

\section{Dissolved oxygen}

Dissolved oxygen dropped close to zero in most of the treatments, to the point that a proper analysis using the final values cannot be made through the Taguchi method. However, taking the graph as a reference, the evolution of the phenomenon can be observed (Figure 7). The treatments that initially had little dissolved oxygen and that fell more quickly to values close to zero, were those that had the highest content of ammonium sulfate, such as $\mathrm{L}_{16}, \mathrm{~L}_{17}, \mathrm{~L}_{18}, \mathrm{~L}_{26}$, and $\mathrm{L}_{27}$. On the other hand, those with the highest sucrose content were the next to drop their values close to zero. And finally, those treatments that remained with slightly higher values at the end of the run were mainly those that contained the lowest values of ammonium sulfate, such as $\mathrm{L}_{10}, \mathrm{~L}_{11}$, and $\mathrm{L}_{12}$.

ANOVA for S/N relations

\begin{tabular}{lrrrrrr} 
SOURCE & GL & \multicolumn{1}{c}{ SS } & Adj. SS & Adj. MS & F & P \\
\hline Sucrose (g) & 2 & 241.398 & 241.398 & 120.699 & 7.03 & 0.006 \\
Ammonium sulfate (g) & 2 & 12.234 & 12.234 & 6.117 & 0.36 & 0.706 \\
Triple superphosphate (g) & 2 & 127.515 & 127.515 & 63.758 & 3.72 & 0.047 \\
Ultra K (g) & 2 & 2.884 & 2.884 & 1.442 & 0.08 & 0.920 \\
Inoculum (g) & 2 & 7.934 & 7.934 & 3.967 & 0.23 & 0.796 \\
Error & 16 & 274.543 & 274.543 & 17.159 & & \\
Total & 26 & 666.509 & & & &
\end{tabular}

Figure 5. Analysis of variance of $\mathrm{S} / \mathrm{N}$ for Absorbance $(\lambda=600 \mathrm{~nm})$.

Table 3. Runs of four broths with the highest absorbance values at $12 \mathrm{~h}$.

\begin{tabular}{|c|c|c|c|c|c|c|}
\hline Run & Sucrose $(\mathbf{g})$ & $\begin{array}{c}\text { Ammonium } \\
\text { sulfate }(g)\end{array}$ & $\begin{array}{c}\text { Triple } \\
\text { Superphosphate }(\mathrm{g})\end{array}$ & Ultra $^{\circledR}(\mathbf{g})$ & Serenade $^{\circledR}(\mathrm{g})$ & $\begin{array}{l}\text { Absorbance } \\
(\lambda=600 \mathbf{n m})\end{array}$ \\
\hline $\mathrm{L}_{22}$ & 772.5 & 181.5 & 6.3 & 5.25 & 1.1 & 0.137 \\
\hline $\mathrm{L}_{26}$ & 772.5 & 302.5 & 18.9 & 1.05 & 3.3 & 0.103 \\
\hline $\mathrm{L}_{23}$ & 772.5 & 181.5 & 6.3 & 5.25 & 3.3 & 0.09 \\
\hline $\mathrm{L}_{24}$ & 772.5 & 181.5 & 6.3 & 5.25 & 5.5 & 0.09 \\
\hline Significance & $* *$ & & $*$ & & & \\
\hline
\end{tabular}




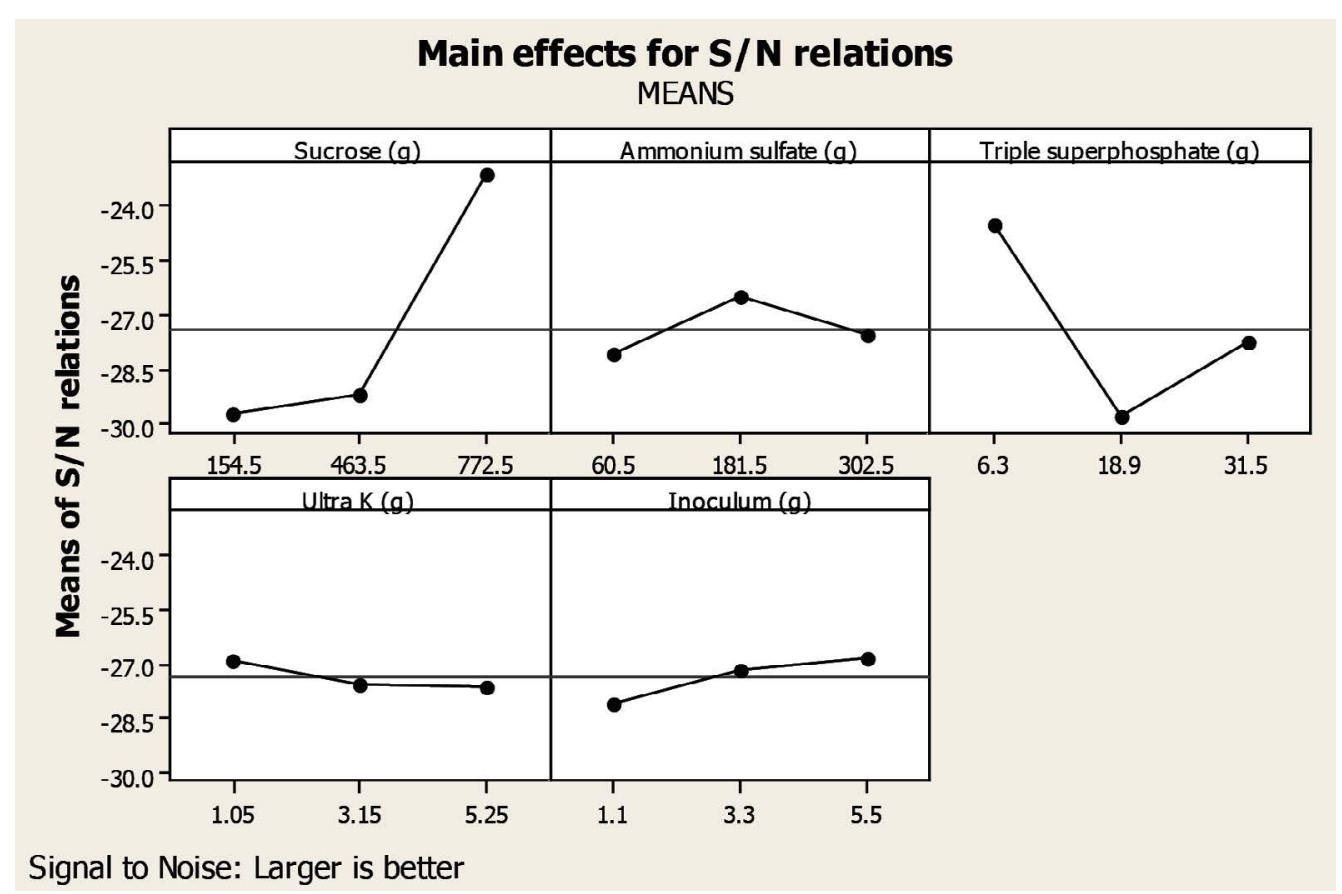

Figure 6. Analysis of the main effects of $\mathrm{S} / \mathrm{N}$ means on the absorbance variable $(\lambda=600 \mathrm{~nm})$ from nine replications.

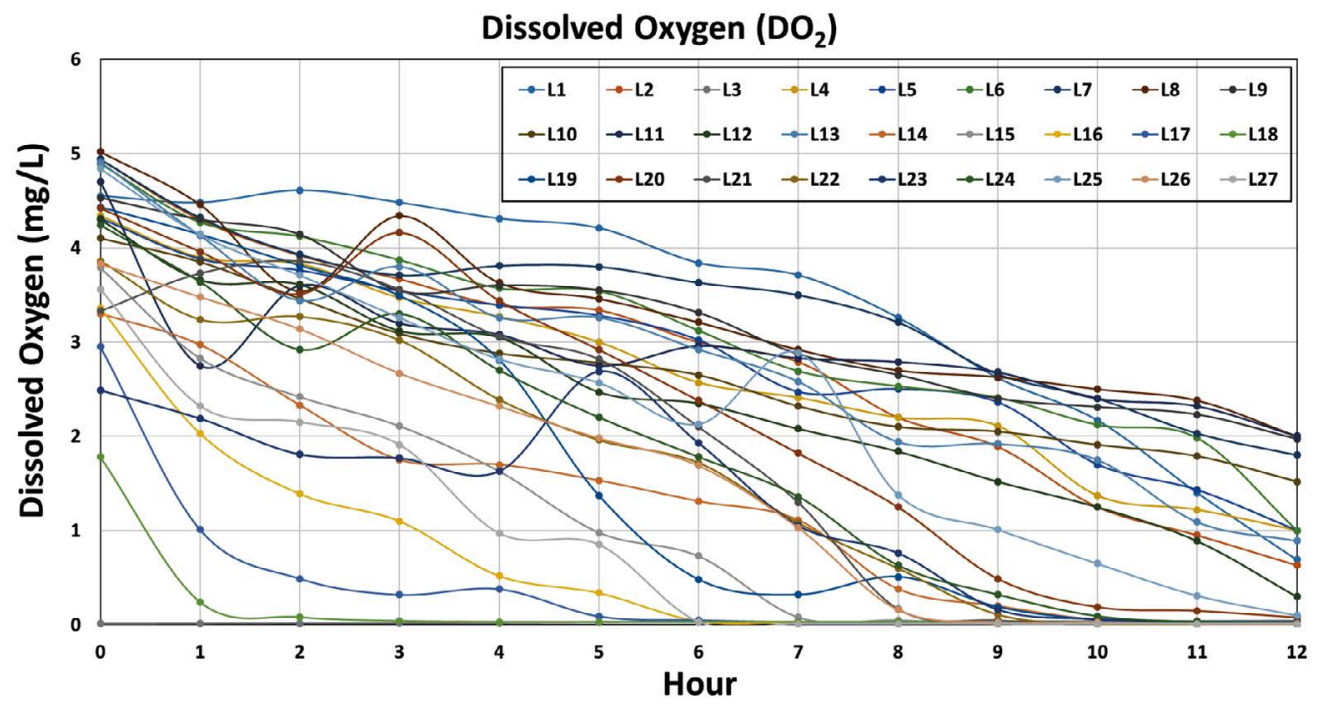

Figure 7. Evolution of dissolved oxygen in the media prepared for the bioreactor.

\section{Temperature and $\mathrm{pH}$}

These two variables did not show appreciable changes throughout the runs. Most of the media were in the 7.0 to $7.5 \mathrm{pH}$ range, with two exceptions that were $6.8\left(\mathrm{~L}_{17}\right.$ and $\mathrm{L}_{18}$ ). Regarding the temperature of the media, it ranged between 17 and $19{ }^{\circ} \mathrm{C}$ in each run without differences among all the cases. This was, perhaps, due to the little variation of temperature within the laboratory. 


\section{GONGLUSIONS}

The media prepared in the selected combinations allowed good discrimination of those that produced greater turbidity derived from cell growth inside the bioreactor, finding that the combinations having the high level of sucrose combined with the low level of triple superphosphate generated the best response. On the other hand, the other factors such as ammonium sulfate, a formulation with potassium $\left(\right.$ UltraK $\left.^{\circledR}\right)$ and the amount of inoculum can be added at their mid or lowest levels because there was no significance for these components of the medium. The presence of high levels of ammonium sulfate caused the content of dissolved oxygen in the medium to drop precipitously, which is why supplying this type of excess should be avoided for a bioreactor of this type. Also, the high amount of sucrose led to a reduction in dissolved oxygen at approximately nine $\mathrm{h}$ after the run, but this may be due to the high bacterial growth as we detected in previous works (De la Cruz-De la Gruz et al., 2016). Sensitivity to oxygenation of B. subtilis under fermentation conditions is decisive for generating adequate bacterial populations (Bourne et al., 1992), and this is important for its application in the field for fertigation, as it is currently performed in a local farm in Pabellón de Arteaga, Aguascalientes (Paulino-Martínez, 2017).

Finally, the $50 \mathrm{~L}$ bioreactor was as efficient as the field bioreactors of which we have experienced since the accelerated growth of B. subtilis was achieved, ensuring that the components of the nutrient medium remained in constant agitation, without "dead zones" that usually affect bacterial growth (Galindo et al., 2007).

\section{REFERENCES}

AgraQuest. (2001). Bacillus subtilis strain QST 713. Report and proposed decision. Monograph, Volume 1. https://www.bvl.bund.de/SharedDocs/Downloads/04_Pflanzenschutzmittel/02_eu_berichte/ BacsubDAR.pdf?__blob=publicationFile\&v=3

Alfonso-Acosta, Y., Pérez-Rojas, A., Yll-Lavín, M. (2019). Diseño de un biorreactor para la producción de inóculo de Salmonella enteritidis. Revista Cubana de Química, 31(1):1-12.

Bourne, J.R., Zurita, E.P., Heinzle, E. (1992). Bioreactor scale-up for the oxygen-sensitive culture Bacillus subtilis: The influence of stirrer shaft geometry. Biotechnology Progress, 8:580-582.

Bratbak, G. \& Dundas, I. (1984). Bacterial dry matter content and biomass estimations. Applied and Environmental Microbiology, 44:755-757

Büchs, J. (2001). Introduction to advantages and problems of shaken cultures. Biochemical Engineering Journal, 7:91-98.

Carvalho, A.L.U., Portella-Corrêa de Oliveira, F.H., Ramos-Mariano, R.L., Ribeiro-Gouveia, E., SoutoMaior, A.M. (2010). Growth, sporulation and production of bioactive compounds by Bacillus subtilis R14. Brazilian Archives of Biology and Technology, 53 (3).643-652.

Cruz-Trejos, E.A., Medina-Varela, P.D., Silva-Diaz, C.A. (2012). Una revisión crítica de la razón señal ruido usada por Taguchi. Scientia et Technica.17 (50):52-56.

De la Cruz-De la Cruz, E., Méndez-Luna, D., Valera-Montero, L.L. (2016). Cultivo de Bacillus subtilis Cepa QST 713 en reactor tipo Airlift y su actividad antagónica contra Phytophthora capsici. Revista de Ingeniería y Tecnologías para el Desarrollo Sustentable 1:38-42.

Galindo, E., Peña, C., Serrano-Carreón, L. (2007). Domesticar microorganismos en un biorreactor: Los retos del bioingeniero. Una ventana al quehacer científico. IBT-UNAM. Biotecnología V14 CS3. 131-143.

Glazyrina, J., Materne, E.M., Dreher, T., Storm, D., Junne, S., Adams, T., Greller, G. Neubauer, P. (2010). High cell density cultivation and recombinant protein production with Escherichia coli in a rockingmotion-type bioreactor. Microbial Cell Factories, 9(42).1-11. Doi: 10.1186/1475-2859-9-42

Katoh, S., Yoshida, F. (2009). Biochemical Engineering: A textbook for engineers, chemists and biologists. Wiley-VCH Verlag GmbH \& Co. KGaA, Weinheim.

Lamping, S.R. (2004). Design of a miniature bioreactor and its use in fermentation and cell culture. Doctoral Thesis of Engineering. University of London. 
Matar, S.M., El-Kazzaz, S.A., Wagih, E.E., El-Diwany, A.I., Moustafa, H.E., El-Saadani, M.A., AboZaid, G.A., Hafez, E.E. (2009). Bioprocessing and scaling-up cultivation of Bacillus subtilis as a potential antagonist to certain plant pathogenic fungi, III. Biotechnology. 8(1).138-143. Doi: 10.3923/ biotech.2009.138.143

Novoselov, A.A., Serrano, P., Alves Forancelli-Pacheco, M.L., Scott-Chaffin, M., O’Malley-James, J.T., Moreno, S.C., Batista-Ribeiro, F. (2013). From cytoplasm to environment: The inorganic ingredients for the origin of life. Astrobiology. 13 (3). 294-302.

Paulino Martínez, E. (2017). Aplicación de Bacillus subtilis y Trichoderma virens para el control de Phytophthora capsici en chile. Tesis de Maestría en Ciencias en Biotecnología Agropecuaria. Instituto Tecnológico El Llano, TecNM.

Pilizota, T., Yang, Y.T. (2018). "Do It Yourself" Microbial cultivation techniques for synthetic and systems biology: cheap, fun, and flexible. Frontiers in Microbiology. 9 (1666). 1-9.

Pleiss, J. (2006). The promise of synthetic biology. Applied Microbiology Biotechnology, 73:735-739. Doi: 10.1007/ s00253-006-0664-3

Scognamiglio, V., Antonacci, A., Lambreva, M.D., Litescu, S.G., Rea, G. (2015). Synthetic biology and biomimetic chemistry as converging technologies fostering a new generation of smart biosensors. Biosensors and Bioelectronics, 74:1076-1086. Doi: 10.1016/j.bios.2015.07.078

Schirmer, C., Dreher, T., Leupold, M., Glaser, R., Castan, A., Brown, J., Eibl, D., Glöckler, R. (2019). Recommendation for biological evaluation of bioreactor performance for microbial processes. Gesellschaft für Chemische Technik und Biotechnologie. Dechema Editors, 36.

Seletzky,J.M., Noak, U., Fricke,J., Welk, E., Eberhard, W., Knocke, C., Büchs, J. (2007). Scale-up from shake flasks to fermenters in batch and continuous mode with Corynebacterium glutamicum on lactic acid based on oxygen transfer and pH. Biotechnology and Bioengineering, 98 (4).800-81 1. Doi: 10.1002/bit.21359

Serrat-Díaz M., Méndez-Hernández, A.A. (2015). Construcción y validación experimental de un biorreactor artesanal tipo tanque agitado para fermentaciones sumergidas a escala de laboratorio. Tecnología Química, 35 (3).317-332.

Theodore, C.M., Loveridge, S.T., Crews, M.S., Lorig-Roach, N. \& Crews, P. (2019). Design and implementation of an affordable laboratory-scale bioreactor for the production of microbial natural products. Engineering Reports 2019; 1:e212059, 1-7. 